Bioeduca: Journal of Biology Education
$\frac{\text { http://iournal.walisongo.ac.id/index.php/bioeduca }}{\text { ISSN 2714-8009 (print), 2715-7490 (online) }}$
Volume 3, Nomor 2, Tahun 2021
Hal. 135 - 145

\title{
Pengembangan Bahan Ajar Berbasis Metode Studi Kasus Terintegrasi Nilai Islam
}

\author{
Inna Saftina ${ }^{1}$, Muhammad Muttaqien ${ }^{2}$, Hadiansah ${ }^{3}$, \\ ${ }^{1,2,3}$ Program Studi Pendidikan Biologi, Universitas Islam Negeri Sunan Gunung Djati Bandung \\ Email : innasaftina@gmail.com
}

\begin{tabular}{|c|c|}
\hline Informasi Artikel & ABSTRAK \\
\hline $\begin{array}{l}\text { Submit: } 19-10-2020 \\
\text { Diterima: } 15-09-2021 \\
\text { Dipublikasikan: } 15-09-2021\end{array}$ & $\begin{array}{l}\text { Hasil wawancara di salah satu MA swasta di kota Bandung, } \\
\text { menunjukkan bahwa sumber belajar yang mampu } \\
\text { mengintegrasikan materi umum dengan nilai-nilai keislaman } \\
\text { sangat dibutuhkan. Penelitian ini bertujuan menghasilkan bahan } \\
\text { ajar berbasis metode studi kasus terintegrasi nilai Islam pada } \\
\text { materi sistem gerak manusia. Metode penelitian menggunakan } \\
\text { R\&D dengan model 4D yang dibatasi sampai pada 3D (define, } \\
\text { design, develop). Subjek penelitian terdiri dari } 20 \text { peserta didik } \\
\text { kelas XI MIA MA Al-Jawami Bandung. Teknik pengumpulan data } \\
\text { dilakukan dengan menggunakan uji validasi ahli materi, media } \\
\text { dan guru mata pelajaran, serta angket uji keterbacaan peserta } \\
\text { didik. Hasil penelitian menunjukkan kategori sangat layak } \\
\text { berdasarkan uji validasi dengan persentase rata-rata } 89 \% \text {. } \\
\text { Bahan ajar diujicobakan secara terbatas dengan hasil uji coba } \\
\text { termasuk kategori sangat layak dengan persentase } 95 \% \text {. } \\
\text { Presentase keseluruhan bahan ajar tersebut yakni } 92 \% \text {, artinya } \\
\text { bahan ajar yang dikembangkan dinilai sangat layak untuk } \\
\text { digunakan sebagai sumber belajar peserta didik di MA. } \\
\text { Kata kunci: bahan ajar; integrasi; nilai Islam }\end{array}$ \\
\hline Penerbit & ABSTRACT \\
\hline $\begin{array}{l}\text { Program Studi Pendidikan } \\
\text { Biologi, Fakultas Sains dan } \\
\text { Teknologi, UIN Walisongo } \\
\text { Semarang }\end{array}$ & $\begin{array}{l}\text { The results of an interview at MA in Bandung, show that learning } \\
\text { resources that are able to integrate with Islamic values are } \\
\text { needed. This study aims to produce teaching materials based on } \\
\text { case study methods integrated with Islamic values in the human } \\
\text { movement system material. The research method uses R\&D with } \\
\text { a } 4 D \text { model that is limited to } 3 D \text { (define, design, develop). The } \\
\text { research subjects consisted of } 20 \text { students of class XI MIA MA } \\
\text { Al-Jawami Bandung. The data collection technique was carried } \\
\text { out using a validation test of material experts, media and subject } \\
\text { teachers, as well as a student readability test questionnaire. The } \\
\text { results showed that the category was very feasible based on the } \\
\text { validation test with an average percentage of } 89 \% \text {. Teaching } \\
\text { materials were tested on a limited basis with the test results } \\
\text { included in the very feasible category with a percentage of } 95 \% \text {. } \\
\text { The overall percentage of the teaching materials is } 92 \% \text {, } \\
\text { meaning that the teaching materials developed are considered } \\
\text { very feasible to be used as learning resources for students in } \\
\text { MA.. } \\
\text { Key words: integrate; teaching materials; Islamic values }\end{array}$ \\
\hline
\end{tabular}

Inna Saftina et al. - Pengembangan Bahan Ajar Berbasis Metode Studi Kasus 


\section{PENDAHULUAN}

Bahan ajar merupakan salah satu sumber belajar, yang memudahkan peserta didik memperoleh sejumlah informasi, pengetahuan, pengalaman, dan keterampilan dalam proses belajar mengajar (Permatasari, 2019), sehingga materi yang disusun dalam bahan ajar harus memudahkan peserta didik untuk menguasai substansi materi pada kompetensi dasar (Ayu \& Lepiyanto, 2019). Bahan ajar ini dapat berbentuk tertulis ataupun tidak tertulis serta berisi seperangkat materi pembelajaran (teaching material) yang disajikan secara runtut, menyeluruh dan menyajikan kompetensi yang harus dikuasai peserta didik dalam proses belajarnya (Rapi, 2012). Oleh karena itu, tersedianya bahan ajar yang berkualitas dapat menjadikan proses belajar lebih efektif, efisien, serta dapat meningkatkan mutu pembelajaran (Ningtyas, 2014).

Sesuai dengan KI 1 dan tujuan kurikulum pembelajaran biologi di madrasah, pembelajaran harus mampu pengintegrasian ilmu biologi dengan nilai Islam. Nilai islam merupakan dasar ilmu pengetahuan yang jelas untuk menerangkan berbagai fenomena alam yang tersaji kemudian di kaji melalui serangkaian proses hingga menghasilkan produk sebagai tanda kebesaran dan kekuasaan Allah Swt. (Rusdiana, 2014). Dengan kata lain, pembelajaran yang diintegrasikan dengan nilai agama, mampu memberikan penanaman nilai pada peserta didik tentang ketuhanan yang sesuai dengan konsep sains (Ihsani, 2020). Maka pengintegrasian ini sangat sesuai demi mewujudkan pembelajaran yang sesuai dengan kebutuhan madrasah (Muspiroh, 2013).

Berdasarkan hasil wawancara yang dilakukan pada guru mata pelajaran Biologi Kelas XI salah satu MA swasta di Bandung, dikemukakan bahwa sekalipun berstatus Madrasah, kebanyakan belum memiliki sumber belajar yang mampu mengintegrasikan nilai Islam dengan perangkat materi sains. Madrasah memiliki tuntutan visi dan misi lebih terarah terhadap bidang agama, namun sampai saat ini belum terdapat sumber yang digunakan berupa bahan ajar yang secara khusus dirancang untuk memenuhi tujuan pengajaran di Madrasah. Dari hasil tersebut didapatkan informasi bahwa pembelajaran belum menunjukkan secara nyata integrasi nilai Islam pada mata pelajaran biologi. Guru telah melakukan upaya perbaikan pembelajaran dengan menerapkan berbagai model pembelajaran, serta mengintegrasikan nilai-nilai karakter secara verbal. Upaya guru belum menunjukkan hasil optimal, hal ini karena bahan ajar yang dipergunakan guru kurang mendukung pencapaian tujuan pembelajaran khususnya di MA tersebut. (Belawati, 2003) menyatakan bahwa bahan ajar bersifat unik sekaligus spesifik. Artinya bahan ajar dapat digunakan untuk tujuan tertentu dan disesuaikan dengan mata pelajaran dan karakteristik peserta didik tertentu juga.

Di lain sisi, untuk memupuk motivasi dan semangat siswa dalam mengolah ide konsep biologi, pembelajaran harus mengupayakan pengalaman belajar nyata pada siswa (Yadav, 2009). Pelajaran yang terpisah dari pengalaman atau kasus riil seharihari akan membuat banyak sekali pelajaran hanya diterima sebagai pengetahuan yang dihafalkan saja. Pengalaman belajar yang bersumber dari kehidupan atau 
kasus sehari-hari dapat membantu siswa cepat memahami makna konsep yang sedang diberikan. Dengan demikian konsep biologi tidak lagi dipahami sebagai konsep abstrak. Alternatif yang dikembangkan antara lain dengan metode studi kasus. Fokus metode ini adalah terdapat pada upaya ilmiah dalam berfikir mengapa dan bagaimana menyelesaikan kasus atau masalah yang disajikan. Atau dapat dikatakan sebagai pembelajaran yang bertolak dari kasus. Guru mengimplementasikan metode ini menggunakan kasus yang bisa dipecahkan sebagai bahan pelajaran. Kasus yang dimaksud dapat menggunakan kasus yang terdapat dalam buku teks maupun sumber-sumber lainnya, bahkan dari kejadian yang benar-benar terjadi di lingkungan sekitar siswa (Sanjaya, 2006).

Kompetensi Dasar pada materi sistem gerak mengangkat kompetensi analisis yang erat kaitannya dengan manusia dan kehidupannya secara nyata. Gangguan yang terjadi padanya sangat banyak ditemui di masyarakat, dan menimbulkan pertanyaan-pertanyaan yang menggiring keingintahuan siswa. Berdasarkan keterangan dari guru mata pelajaran yang bersangkutan, tingkat respon siswa pada materi ini cukup tinggi dari tahun ke tahun, namun materi ini dianggap sulit bagi siswa karena membutuhkan kemampuan untuk mengingat dan menghafal macammacam rangka, bagian rangka dalam jumlah banyak apalagi ditambah dengan visualisasi yang kurang menarik sehingga sukar untuk dihafalkan. Selain itu, materi sistem gerak termasuk kedalam kelompok pengajaran anatomi dan fisiologi manusia yang sering memperkenalkan subyek (deskripsi proses penyakit, prosedur klinis dan masalah kesehatan dan kebugaran) yang dieksplorasi atau ditekankan secara lebih rinci pada kasus klinis yang lebih maju. Sebuah kasus yang berhubungan dengan penyakit atau patologi sering memperdalam pemahaman siswa tentang anatomi manusia normal dan fisiologi, sehingga membuktikan relevansi kehidupan nyata secara langsung (Cliff \& Wright, 2007).

Bahan ajar berbasis modul elektronik dengan terintegrasi nilai Islam telah banyak dilakukan pada penelitian sebelumnya, dan terbukti efektif sebagai tambahan materi yang sesuai dengan $\mathrm{KI} 1$. Akan tetapi terdapat kebaruan pada penelitian ini. Materi umum diintegrasikan dengan nilai Islam dan studi kasus sekaligus, sehingga diharapkan dapat membantu memudahkan peserta didik dalam menguasai materi secara lebih riil serta sesuai dengan tuntutan dan kebutuhan kurikulum di Madrasah.

\section{METODE PENELITIAN}

Metode penelitian yang dilakukan adalah Research and Development (R\&D) dengan tahapan penelitian dibatasi sampai 3D (Define, Design, dan Devolep) (Thiagarajan, 1974). Pembatasan ini dilakukan dengan mempertimbangkan aspek waktu, biaya (Elvarita, 2020), serta kondisi di tengah pandemi. Penelitian disederhanakan hanya sampai pada dihasilkannya produk setelah dilakukan uji coba terbatas. Merujuk pada Sukmadinata (2010), bahwa penelitian untuk program S1 dan S2 dapat dihentikan sampai dihasilkan draft final tanpa pengujian hasil. 
Penelitian dilaksanakan pada bulan Juli 2020 di MA Al-Jawami Bandung. Sumber data berasal dari satu orang validator materi dan media, serta lima orang guru biologi dan 20 orang peserta didik kelas XI MIA. Prosedur pengembangan meliputi tahap define, design atau dan develop. Tahap define atau pendefinisian merupakan tahapan studi pendahuluan berupa analisis studi lapangan dan studi pustaka untuk mengumpulkan informasi awal terkait kebutuhan pembelajaran yang dimaksud. Tahapan ini meliputi analisis ujung depan yang bertujuan untuk menganalisis masalah yang dihadapi oleh guru dalam pembelajaran, analisis peserta didik bertujuan untuk menganalisis masalah yang dihadapi oleh peserta didik dalam pembelajaran, analisis tugas, analisis konsep dan analisis tujuan pembelajaran yang bertujuan untuk menganalisis dari segi kebutuhan materi dan kurikulum. Kompetensi dasar yang dipilih adalah KD 3.5 yakni menganalisis hubungan antara struktur jaringan penyusun organ pada sistem gerak dan mengaitkan dengan bioprosesnya sehingga dapat menjelaskan mekanisme gerak serta gangguan fungsi yang mungkin terjadi pada sistem gerak manusia. Tahapan kedua yakni design atau perancangan prototype produk yang meliputi penetapan kriteria acuan dalam membuat produk, pemilihan media dan format serta merancang produk awal. Tahap ketiga yakni develop atau pengembangan, meliputi validasi ahli yang terdiri dari ahli materi, ahli media dan guru mata pelajaran, serta uji terbatas dengan dilakukannya uji keterbacaan peserta didik terhadap bahan ajar.

Hasil validasi dan uji keterbacaan peserta didik selanjutnya dikategorikan berdasarkan rerata persentase menururt kriteria masing-masing seperti yang terdapat pada Tabel 1. dan Tabel 2. berikut ini.

Tabel 1. Kriteria Kelayakan Hasil validasi

\begin{tabular}{|c|c|}
\hline Persentase & Kategori \\
\hline $81-100 \%$ & Sangat layak \\
\hline $61-80 \%$ & Layak \\
\hline $41-60 \%$ & Cukup layak \\
\hline $21-50 \%$ & Kurang layak \\
\hline $0-20 \%$ & Sangat kurang layak \\
\hline
\end{tabular}

(Sumber : Akbar, 2013)

Tabel 2. Persentase Hasil Tanggapan Peserta Didik

\begin{tabular}{|c|c|}
\hline Persentase & Kategori \\
\hline $81-100 \%$ & Sangat layak \\
\hline $61-80 \%$ & Layak \\
\hline $41-60 \%$ & Cukup layak \\
\hline $21-50 \%$ & Kurang layak \\
\hline $0-20 \%$ & Sangat kurang layak \\
\hline
\end{tabular}

(Sumber : Akbar, 2013)

\section{HASIL PENELITIAN DAN PEMBAHASAN}

Hasil penelitian ini berupa produk bahan ajar berbasis metode studi kasus terintegrasi nilai islam yang dikembangkan untuk kemudian divalidasi oleh validator. 
Berdasarkan rumusan masalah yang diteliti, hasil penelitian ini mencakup validasi bahan ajar dan respon keterbacaan bahan ajar tersebut.

\section{Hasil validasi}

Validasi (uji kelayakan) dilakukan kepada satu orang validator ahli materi, satu orang ahli media dan lima orang guru mata pelajaran yang tergabung dalam MGMP Biologi MA Kab. Bandung, dengan hasil persentase kelayakan dapat dilihat seperti pada Gambar 1. berikut.

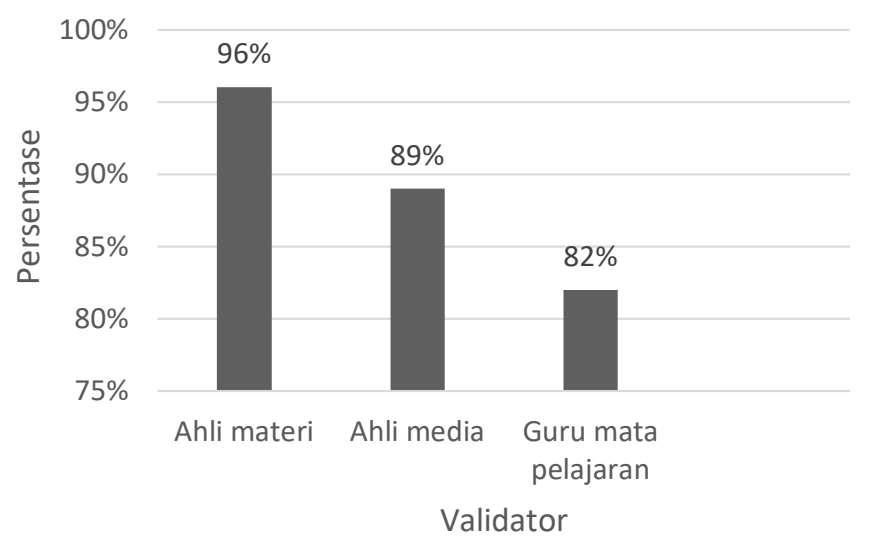

\section{Gambar 1. Grafik Hasil Uji Validasi terhadap Tiga Validator}

Ahli materi bertugas untuk memvalidasi aspek kelayakan isi, kelayakan penyajian, penyajian bahasa (Astuti et al. 2016), dan keterapaduan nilai islam. Penilaian validator ahli materi rata-rata memperoleh nilai sangat baik. Dilihat dari aspek kelayakan isi dimana materi telah sesuai dengan KD dan tujuan pembelajaran, materi akurat berdasarkan konsep dan data, serta mampu mendorong sikap inquiry peserta didik. Aspek penyajian dinilai sangat baik dari segi konsistensi, kelogisan serta keruntutan penyajian, kejelasan dan eksistensi berbagai elemen penunjang materi. Aspek penyajian bahasa mendapatkan penilaian sangat baik dari segi ketepatan bahasa, ejaan dan istilah, serta penggunaan bahasa mampu mendorong peserta didik dalam merespon pesan yang disajikan. Ulfah (2018) menjelaskan bahwa penggunaan bahasa dalam bahan ajar berkaitan dengan pemilihan ragam bahasa, pemilihan kata, penggunaan kalimat efektif, dan penyusunan paragraf yang bermakna. Hal tersebut perlu diperhatikan karena penggunaan bahasa yang tepat akan membantu pengguna bahan ajar untuk memahami informasi atau instruksi yang diberikan dengan baik. Kemudian dari aspek keterpaduan materi dengan nilai islam, validator menilai bahwa bahan ajar telah mengandung unsur nilai islam secara jelas, materi keislaman sesuai dengan al-qur'an dan hadist, serta sesuai dengan kaidah moral yang seharusnya. Grafik persentase penilaian ahli materi selengkapnya ditampilkan pada gambar 2. berikut. 


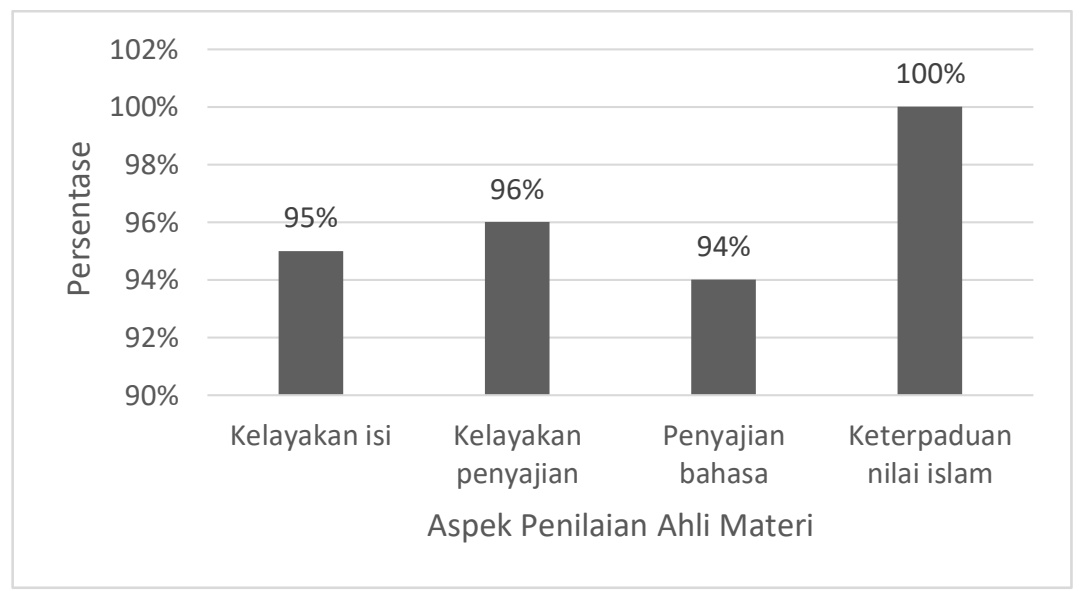

\section{Gambar 2. Grafik Penilaian Ahli Materi}

Ahli media bertugas untuk memvalidasi aspek penyajian dan kegrafikan dari produk yang dikembangkan (Pranata et al. 2016), meliputi ukuran bahan ajar, desain sampul dan desain isi bahan ajar. Penilaian validator ahli media rata-rata memperoleh nilai sangat baik. Dilihat dari aspek ukuran bahan ajar dimana ukuran tersebut telah sesuai dengan standar ISO dan proporsi isi. Aspek desain sampul dinilai memiliki unsur keharmonisan, komposisi dan ukuran tata letak, menampilkan pusat pandang yang baik, serta menggambarkan isi materi ajar. Ukuran bahan ajar, keharmonisan warna dan keproporsionalan tata letak bahan ajar mempengaruhi kemenarikan bahan ajar. Bahan ajar yang menarik dapat membantu meningkatkan motivasi belajar siswa dalam menggunakan bahan ajar yang dikembangkan (Ulfah, 2018). Selanjutnya dari aspek desain isi bahan ajar yang memiliki lima belas (15) butir indikator mendapatkan penilaian rata-rata sangat baik dengan kriteria penggunaan huruf dan ilustrasi yang sesuai, bidang cetak serta pemisahan paragraf dalam teks serasi, dan secara keseluruhan desain isi bahan ajar dinilai kreatif dan dinamis. Hal tersebut sejalan dengan penjelasan Sadjati (2016) yang memaparkan bahwa ilustrasi digunakan untuk memperjelas pesan atau informasi yang disampaikan. Selain itu, dengan adanya ilustrasi yang tepat, bahan ajar dapat terlihat menarik, memotivasi, komunikatif, serta membantu retensi dan pemahaman mahasiswa terhadap isi materi yang disajikan dalam bahan ajar. Grafik persentase penilaian ahli media selengkapnya ditampilkan pada gambar 3. berikut.

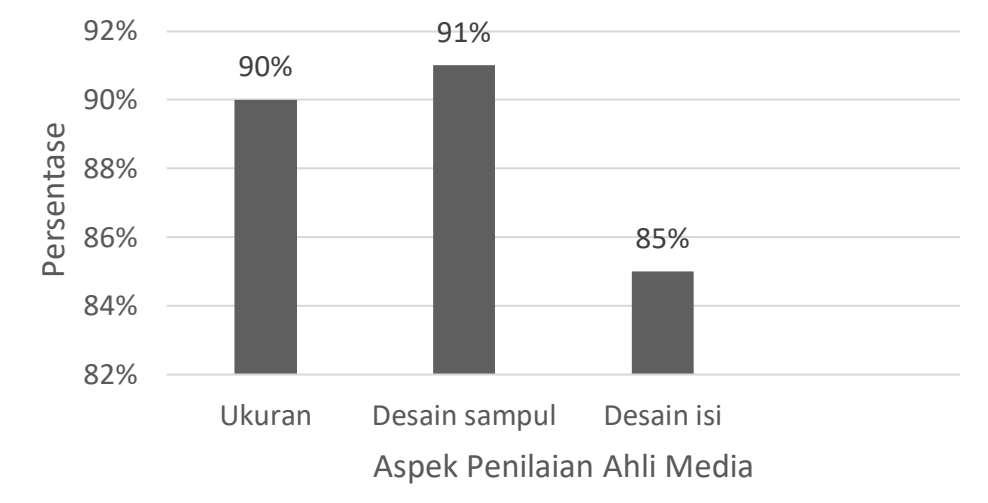

Gambar 3. Grafik Penilaian Ahli Media 
Selain divalidasi oleh dosen ahli materi dan desain, bahan ajar juga dinilai oleh lima orang guru mata pelajaran yang tergabung dengan MGMP biologi MA se-Kab. Bandung, mencakup guru mata pelajaran biologi kelas XI di MA Al-Jawami. Ahli praktisi lapangan atau guru mata pelajaran bertugas untuk memvalidasi aspek isi, penyajian, kegrafikan, dan bahasa (Pranata et al., 2016). Masukan dari guru mata pelajaran tidak menyebabkan perubahan pada bahan ajar yang dikembangkan. Penilaian guru rata-rata memberikan respon setuju dan sangat setuju terhadap bahan ajar yang dikembangkan, terbukti dari hasil angket yang disebar mengatakan bahwa ajar tersebut sangat bermanfaat untuk diterapkan di lingkungan MA khususnya, karena selain telah sesuai dengan apa yang terdapat dalam kompetensi dasar serta tujuan pembelajaran, juga mengandung nilai lebih dengan menyajikan nilai islam yang terintegrasi dengan konsep biologi. Sehingga diharapkan dapat membantu tercapainya kurikulum dalam pembelajaran di madrasah. Selain penilaian tersebut, terdapat beberapa masukan dari ahli materi, ahli media serta guru yakni terkait kejelasan keterangan gambar, penambahan unsur ensiklopedia umum, serta kejelasan huruf dalam teks islamic values. Berdasarkan masukan yang diberikan, beberapa perbaikan dilakukan untuk memenuhi kelayakan isi bahan ajar. Hal ini dikuatkan oleh pernyataan bahwa tingkat keterbacaan suatu modul atau bahan ajar dipengaruhi oleh beberapa faktor, diantaranya susunan dan cara penulisan kata dalam kalimat, kemudian struktur paragraf dan diksi yang digunakan (Sitepu, 2012). Grafik persentase penilaian guru mata pelajaran selengkapnya ditampilkan pada gambar 4. berikut.

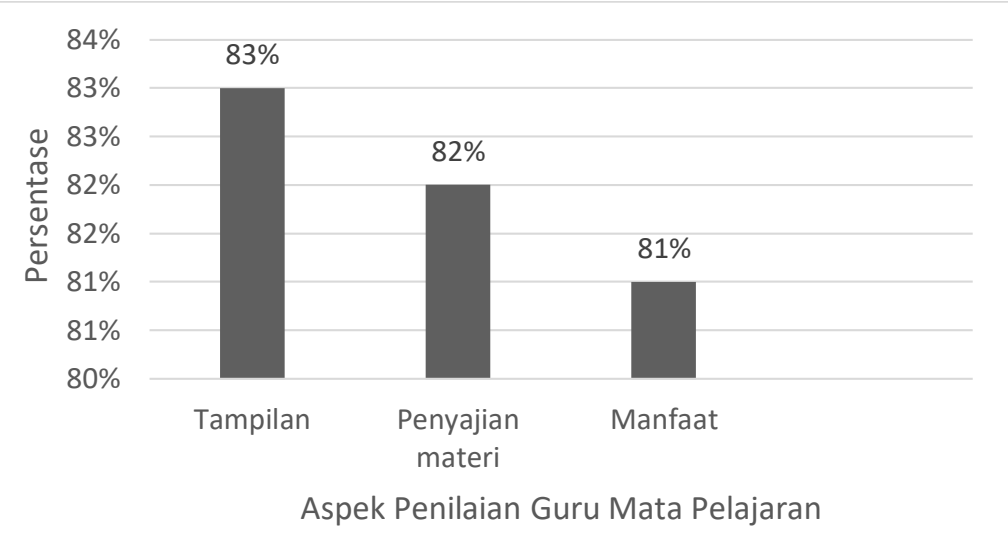

\section{Gambar 4. Grafik Penilaian Guru Mata Pelajaran}

Menurut Akbar (2013), apabila perangkat pembelajaran yang dikembangkan bernilai sangat valid, maka memiliki arti bahwa produk tersebut dapat digunakan tanpa revisi. Penilaian ahli tidak dapat dijadikan satu-satunya sumber yang menunjukkan kelayakan dari produk yang dikembangkan. Menurut Sukmadinata (2012), validasi ahli menghasilkan nilai kelayakan produk secara makro sehingga diperlukan uji skala kecil yang dapat memberikan penilaian secara mikro. Oleh sebab itu, kelayakan bahan ajar harus menggabungkan hasil validasi ahli dan siswa.

Dari hasil validasi produk, terdapat saran dari validator berupa penambahan Islamic Values pada bahan ajar, penambahan ensiklopedia umum, serta pengubahan jenis font pada Islamic Values agar lebih mudah dibaca. Adapun secara 
keseluruhan, validator menilai bahan ajar yang dikembangkan sudah sangat baik, menarik dan bermanfaat jika diterapkan pada pembelajaran. Berikut merupakan tampilan bahan ajar berbasis metode studi kasus terintegrasi nilai islam pada materi sistem gerak manusia.

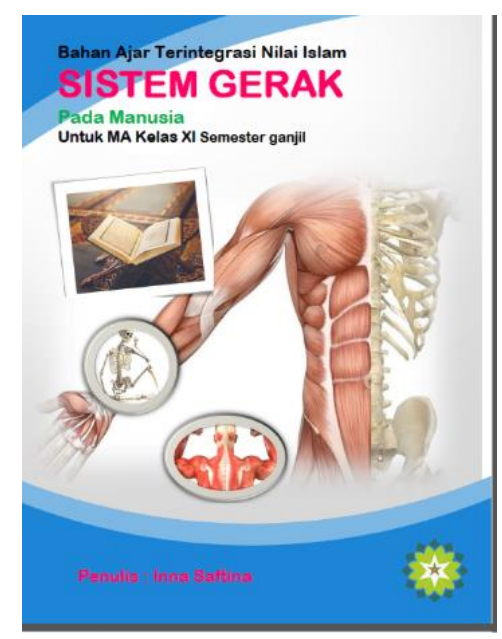

Gambar 5. Tampilan Cover Bahan Ajar Sistem Gerak
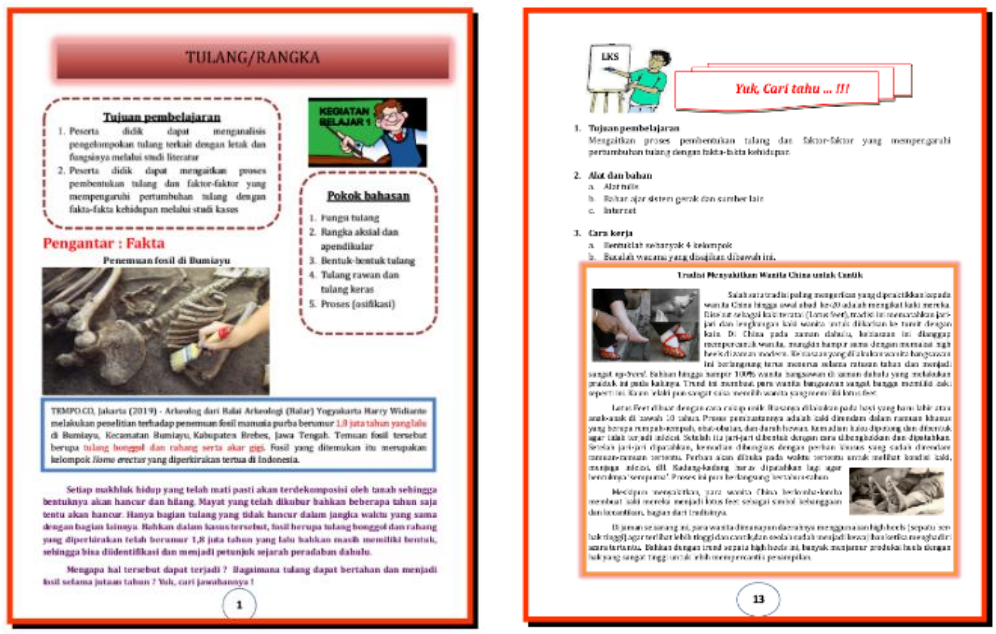

Gambar 6. Tampilan Isi Pendahuluan Materi dan Lembar Kerja Berbasis Studi Kasus

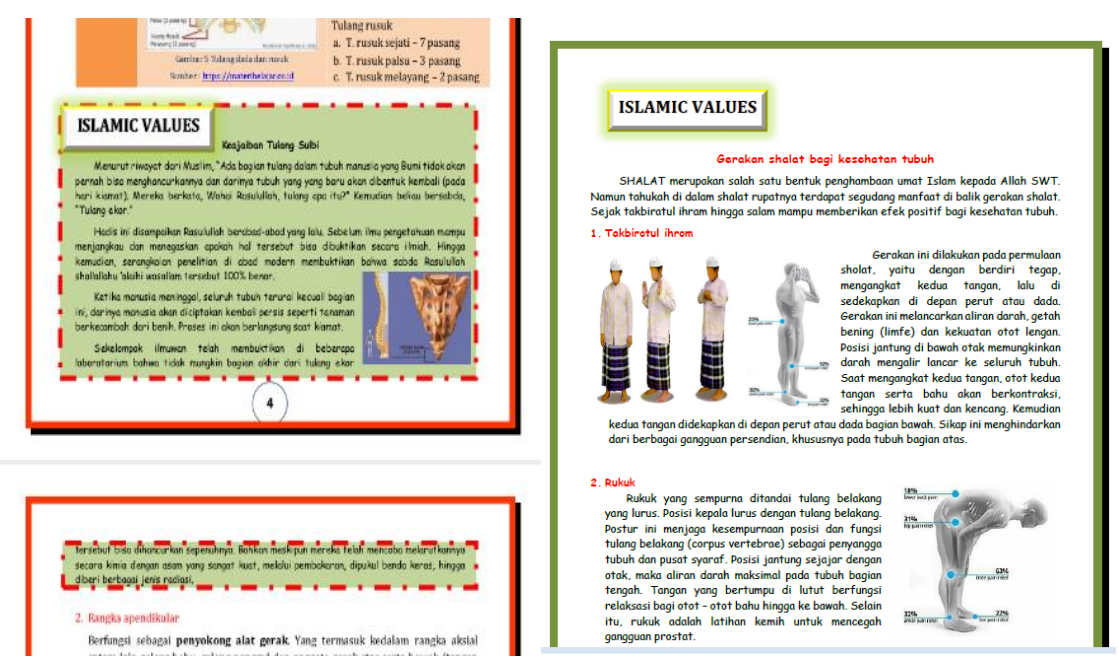

Gambar 7. Tampilan Isi Integrasi Nilai Islam pada Bahan Ajar 


\section{Hasil Uji Terbatas}

Uji coba terbatas dilakukan dengan melakukan uji keterbacaan yang diberikan kepada delapan peserta didik untuk memberikan tanggapan terkait bahan ajar yang dikembangkan. Uji keterbacaan peserta didik dilakukan untuk memperoleh nilai kelayakan dari produk yang dikembangkan dan diharapkan juga adanya masukan baik berupa komentar, saran, dan kritik untuk perbaikan produk (Sukmadinata, 2012). Hasil tanggapan peserta didik dapat dilihat pada grafik gambar 5. dibawah ini.

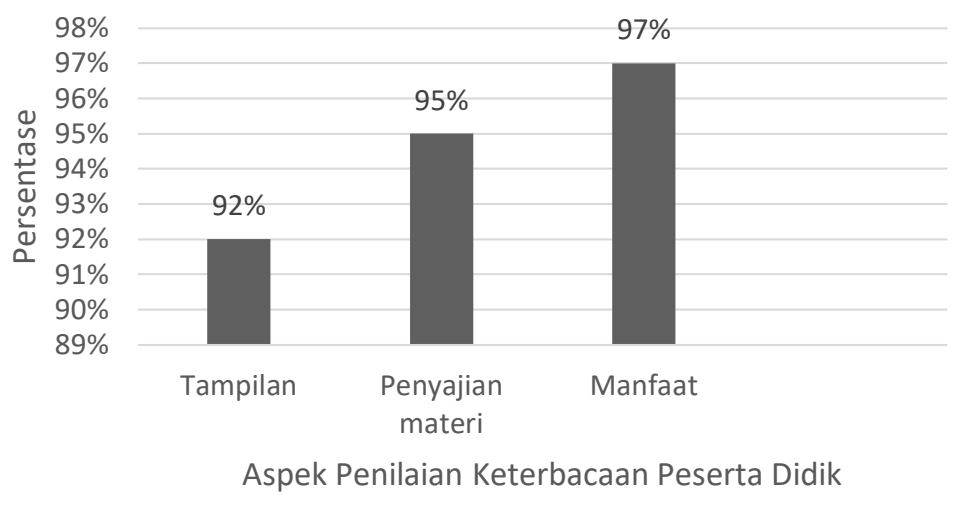

\section{Gambar 8. Grafik Penilaian Tanggapan Keterbacaan Peserta Didik}

Menurut Prayitno (2017), produk pengembangan yang mendapat nilai uji keterbacaan sangat baik memiliki arti dapat digunakan tanpa revisi. Kesimpulan dari kelayakan suatu produk yang dikembangkan dapat dibuat dengan menggabungkan data validasi ahli dan uji keterbacaan siswa (Sukmadinata, 2012). Maka kesimpulan yang dapat diambil berdasarkan data tersebut adalah bahan ajar berbasis metode studi kasus terintegrasi nilai islam bersifat sangat valid dan baik sehingga layak untuk digunakan pada tahap disseminate. Adapun tahap disseminate tidak dilakukan dalam penelitian ini karena metode pengembangan yang dibatasi hanya sampai tahap 3-D.

\section{SIMPULAN DAN SARAN}

Berdasarkan hasil penelitian pengembangan bahan ajar berbasis metode studi kasus terintegrasi nilai islam pada materi sistem gerak manusia yang dikembangkan melalui tahapan 3-D (define, design dan develop), dapat diperoleh kesimpulan yang menyatakan bahwa hasil validasi bahan ajar berbasis metode studi kasus terintegrasi nilai islam pada materi sistem gerak manusia berada pada kategori sangat layak untuk digunakan dengan persentase $89 \%$, serta hasil keterbacaan bahan ajar berbasis metode studi kasus terintegrasi nilai islam pada materi sistem gerak manusia berada pada kategori sangat layak dengan persentase 95\%. Adapun saran dari penelitian ini antara lain perlu adanya peningkatan kesadaran dan kreatifitas guru dalam aspek pengembangan sumber belajar efektif yang lebih disesuaikan dengan tujuan madrasah, salah satunya mengembangkan bahan ajar terintegrasi nilai islam pada materi pembelajaran lainnya. Kemudian bagi peneliti yang akan melakukan pengembangan lanjutan, diharapkan dapat melakukan uji 
lapangan dalam skala besar dan memperoleh analisis pengaruh penggunaan bahan ajar berbasis metode studi kasus terintegrasi nilai islam pada materi sistem gerak manusia terhadap kompetensi peserta didik.

\section{UCAPAN TERIMA KASIH}

Ucapan terimkasih kepada Dosen pembimbing I dan II yaitu Bapak Drs.Muhamad Muttaqien, M.Pd dan Bapak Hadiansah, M. Pd, serta validator dan guru serta sekolah yang dijadikan tempat penelitian yang telah membantu dalam penelitian ini.

\section{RUJUKAN}

Akbar, S. (2013). Instrumen Perangkat Pembelajaran. Bandung: PT Remaja Rosdakarya.

Astuti, R., Ruqiah G. P. P., Titin. (2016). Kelayakan Media Komik Elektronik pada Pembelajaran Submateri Zat Aditif di SMP. Jurnal Pendidikan dan Pembelajaran Khatulistiwa. 5(8), 1-13.

Ayu, Yolanda Patrica \& Lepiyanto, Agil. (2019). Pengembangan Modul Berbasis POE (Predict, Observe, Explain) Terintegrasi Nilai Keislaman Materi Jaringan Tumbuhan. Jurnal Bioterdidik. 7(4), 53-63.

Belawati, T. (2003). Pengembangan Bahan Ajar. Jakarrta: Universitas Terbuka.

Cliff, William H. \& Wright, Ann W. (2007). Directed Case Study Method For Teaching Human Anatomy And Physiology. Advan Physiol Educ. 15(1), 19-28.

Elvarita, A., Iriani, T., \& Handoyo, S.S. (2020). Pengebangan Bahan Ajar Mekanka Tanah Berbasis E-Modul pada Program Studi Pendidikan Teknik Bangunan. JPenSil. 9(1), 1-7. https://doi.org/10.21009/jpensil.v9i1.11987

Ihsani, Nurul, Idrus, A.A., \& Jamaludin, J. (2020). Perangkat Pembelajaran Biologi Berbasis Masalah Terintegrasi Nilai-Nilai Islami untuk Meningkatkan Penguasaan Konsep Peserta Didik. J. Pijar MIPA. 5(2), 103-109. http://doi.org/ 10.29303/Jpm.V15i2.1326

Muspiroh, N. (2013). Integrasi Nilai Islam dalam Pembelajaran IPA (Perspektif Pendidikan Islam). Jurnal Pendidikan Islam: Islamic Educational Institution Concerning Islamic Education. 38(3), 484-498.

Ningtyas, E, A., Sumarni, W., \& Christijanti, W. (2014). Pengembangan Modul IPA Terpadu Berbasis SETS dengan Tema Hujan Asan untuk Kelas VII SMP. Unnes Science Education Journal. 3(1), 438-444. http://doi.org/438-444. http://doi.org/10.15294/USEJ.V3I1.2970

Permatasari, I., Ramdani, A., \& Syukur, A., (2019). Pengembangan Bahan Ajar IPA Berbasis Inkuiri Terintegrasi SETS (Science, Environment, Technology and Society) pada Materi Sistem Reproduksi Manusia. Jurnal Pijar MIPA. 3(13). 74-78. http://doi.org/10.29303/Jpm.V14i2.1256

Pranata, B. D. (2016). Pengembangan Modul Pembelajaran Biologi Berbasis Discovery Inquiry pada Materi Sistem Reproduksi untuk Siswa Kelas XI SMA. Skripsi. Fakultas Matematika dan Ilmu Pengetahuan Alam Universitas Malang. 
Prayitno, S. H., \& L.adyawati, E. (2017). Pengembangan Modul Matematika Diskrit untuk Meningkatkan Multiple Intelligences Mahasiswa Universitas PGRI Adi Buana Surabaya. Seminar Nasional Matematika dan Aplikasinya. 28 Oktober 2017. Universitas Airlangga Surabaya.

Rapi, M. (2012). Pengantar Strategi Pembelajaran (Pendekatan Standar Proses). Makassar: Alauddin University Press

Rusdiana, A. (2014). Integrasi Pendidikan Agama Islam dengan Sains dan Teknologi. Jurnal Istek. 8(2), 123-143.

Sadjati,I. M. (2016). Pengembangan Bahan Ajar. Jakarta: Universitas Terbuka.

Sanjaya, W. (2006). Strategi Pembelajaran. Jakarta: Kencana Prenada Media Group.

Sitepu, B. P. (2012). Penulisan Buku Teks Pelajaran. Bandung: PT Remaja Rosdakarya Offset.

Sukmadinata, N. S. (2012). Metode Penelitian Pendidikan, Bandung: PT Remaja Rosdakarya

Thiagarajan, S., Semmel D. S., \& Semmel M.I. (1974). Instructional Development for Training Teacher of Exceptional Children. Bloomington Indiana: Indiana University.

Ulfah, A. \& Jumaiyah. (2018). Pengembangan Bahan Ajar Mata Kuliah Bahasa Indonesia di Perguruan Tinggi Kabupaten Lamongan. Jurnal Inovasi Pendidikan. 2(1), 75-81.

Yadav, A \& Janna, L. B. (2009). Implementing Case Studies in a Plant Pathology Course: Impact on Student Learning and Engagement. Journal National Resour. Life Sciences. Education. 38(1), 50-55. 